\title{
Book Review -The High Road Code: Business Ethics, Personal Branding \& Leadership in Action by Doug McAlister
}

\author{
Alexander Franco, Ph.D. \\ Director, Centre for International Business and Educational Research, Strategy First Institute \\ alexander@mystrategyfirst.com
}

As a teacher of business ethics courses, this reviewer has had to struggle with the necessity of using textbooks that provide the theory and nomenclature of the subject. The material, quite often, can be dry and the case studies accompanying the texts can be technically dull and non-inspiring. I always hoped to find a book on ethics written by a real practitioner who was not in prison writing about crimes he committed. The High Road Code is such a book.

The author has forty years of experience in the business world from entry level to senior management positions in Proctor \& Gamble and Coca Cola. He is currently the founder of The Bravo-Zulu Consulting Group, LLC. Before delving into the substance of this work, I must commend the author on the way the book was written and of the presentation of the material. The text avoids jargon, the language flows easily and can be easily understood by laymen. The author does not seek to impress and his message is clear and consistent. The personal anecdotes he injects throughout the book reinforce his points in a way that a non-practitioner could never achieve. Einstein was quoted as saying that if you can't explain something simply, you don't understand it well enough. The simplicity in the presentation of the message in this book clearly demonstrates the mastery of the subject by the author which he obtained through his trials and tribulations over forty years of real experience. This is not a book meant for insiders and yet you feel privileged to hear from one who was.

This work is structured in eight chapters with the first three serving as the foundation for the rest of the book. These first three chapters address the value of personal integrity and its implementation into a personal brand. Chapters 5 to 8 then look into the development of leadership skills, the creation of customer satisfaction, and the building of teams in a work environment - all of these efforts within an ethical framework - as well as the importance of introducing and then guarding your personal brand within the often perilous realm of networking.

The fundamental message of the book is simple yet difficult to achieve: one succeeds best through a life-long journey of traveling on the "high road" - a path that relies on the development and maintenance of your personal integrity as well as its incorporation into your business environment. Integrity, as the author sees it, requires an unwavering commitment to do the right thing. In doing so you create your own personal brand, a brand that is nurtured and protected like any respectable corporate brand and which helps you achieve your goals, gain respect for your leadership and create an inner sense of self-esteem and pride.

Two very practical chapters in the book incorporate ethics within the practice of leadership and in teambuilding. It is particularly refreshing to see the author stress that a work group and a team are not the same and that all work groups are not meant to be teams. As the author sees it, a team is a creation cemented by a vision that seeks high but reasonable standards of success though fierce competition within a framework committed to personal and corporate integrity. Most importantly, this all works best with leadership that promotes accountability, transparency, fairness and an environment where leaders lead by personal example. 

by Doug McAlister

This book comes at a much needed time when the cut-throat managerial tactics of acknowledged sociopaths in the workforce are being celebrated, even emulated, by many writers. The greatest danger is that such a trend threatens to create a business zeitgeist where few institutional attempts are made to identify or punish sociopaths, causing those in the lower rungs to justify and even defend those who have risen higher up the corporate ladder by utilizing sociopathic, predatory and disruptive behavior. So much contemporary literature in the United States unfortunately romanticizes sociopaths, crediting them with higher intelligence quotients

than most and more business success than they have actually achieved. The current state begs for some sort of mystical re-start button to be pressed. If I could, I would blister my finger pressing one. However, in developing nations, where much is still in an early stage of modern business development, it would benefit these countries for those entering the workforce in general, and the business world in particular, to read this book.

With that said, it is important to understand two vitally important points from this book. The first is that you can join onto the high road at any time in your life; it is never too late. And, second is to remember that fallibility, being part of the human condition, may cause you to stray from that high road, now and then, here and there, into twisted pathways. But knowledge of the location of the high road for a return, utilizing your moral compass, is always there.

\section{References}

Doug McAlister, The High Road Code: Business Ethics, Personal Branding \& Leadership in Action, BravoZulu Consulting Group, LLC, pp. 128, ISBN-10: 0692973540, ISBN-13: 978-0-6929-2065-7

Citation: Alexander Franco, Ph.D., "Book Review -The High Road Code: Business Ethics, Personal Branding \& Leadership in Action by Doug McAlister." American Research Journal of Business and Management. 2018; 4(1): 1-2.

Copyright (c) 2018 Alexander Franco, Ph.D., This is an open access article distributed under the Creative Commons Attribution License, which permits unrestricted use, distribution, and reproduction in any medium, provided the original work is properly cited. 